\title{
Anti-LAG3 Monoclonal Antibody BI 754111
}

National Cancer Institute

\section{Source}

National Cancer Institute. Anti-LAG3 Monoclonal Antibody BI 754111. NCI Thesaurus.

Code C150403.

A monoclonal antibody directed ag ainst the inhibitory receptor lymphocyte activation gene 3 protein (LAG3; LAG-3), with potential immune checkpoint inhibitory and antineoplastic activities. Upon administration, the anti-LAG3 monoclonal antibody B I 754111 binds to LAG3 expressed on tumor-infiltrating lymphocytes (TILs) and blocks its binding with major histocompatibility complex (MHC) class II molecules expressed on tumor cells. This activates antigen-specific T-lymphocytes and enhances cytotoxic T-cellmediated tumor cell lysis, which leads to a reduction in tumor growth. LAG3, a member of the immunog lobulin superfamily (IgSF), is expressed on various immune cells, and negatively regulates both proliferation and activation of T-cells. Its expression on TILs is associated with tumor-mediated immune suppression. 